\title{
KEMAMPUAN BERHITUNG PERMULAAN ANAK TAMAN KANAK-KANAK KELOMPOK B SE-KELURAHAN LENGKONGSARI KOTA TASIKMALAYA
}

\author{
Maya Maesaroh ${ }^{1}$, Sumardi $^{2}$, Lutfi Nur $^{3}$ \\ ${ }^{1}$ Program Studi PGPAUD UPI Kampus Tasikmalaya \\ ${ }^{2}$ Program Studi PGPAUD UPI Kampus Tasikmalaya \\ ${ }^{3}$ Program Studi PGPAUD UPI Kampus Tasikmalaya
}

Email : Mayamaesaroh@gmail.com

(Received: Mei 2019; Accepted: Mei 2019; Published: Juni 2019)

\begin{abstract}
This study aims to determine the ability to count the beginning of kindergarten children group B village Lengkongsari Tasikmalaya City. This is based on the importance of numeracy skills for early childhood. In addition, the ability to start counting also needs to be developed so that children have the readiness to continue to higher education again that is elementary school. This research is descriptive research using survey method. Population in this research is kindergarten children group B Se-village Lengkongsari Tasikmalaya City. The data retrieval technique is using purposive sampling. The population of this research is Children of Kindergarten of Lengkongsari Urban Village. The results of data analysis of early numeracy skills include the ability to split the numbers 1-10, write 1-10 numbers, the ability of addition and reduction of 1-10 numbers. The ability to spell shows an average of 9.87. In terms of criteria according to Acep Yoni the ability to count is very well developed. Ability to write an average of 9.53 and is in the criteria developed very well. Furthermore, the summation ability of 9.25 and the average abatement capability is 9.08 and is in excellent growing criteria.
\end{abstract}

Keywords : Early Counting Abiliti, Spelling, Writing, Addition, Reduction

\begin{abstract}
ABSTRAK
Penelitian ini bertujuan untuk mengetahui kemampuan berhitung permulaan anak TK kelompok B Se-kelurahan Lengkongsari Kota Tasikmalaya. Hal ini dilatar belakangi oleh pentingnya kemampuan berhitung untuk anak usia dini. Selain itu kemampuan berhitung permulaan juga perlu dikembangkan sehingga anak memiliki kesiapan melanjutkan ke pendidikan yang tinggi lagi yaitu sekolah dasar. Penelitian ini adalah penelitian deskriptif dengan menggunakan metode survey. Populasi dalam penelitian ini adalah anak TK kelompok B Sekelurahan Lengkongsari Kota Tasikmalaya. Teknik pengambilan data yaitu menggunakan sampling purposive. Hasil analisis data mengenai kemampuan berhitung permulaan yang meliputi kemampuan membilang angka 110, menulis angka 1-10, kemampuan penjumlahan dan pengurangan angka 1-10. Kemampuan membilang menunjukan rata-rata sebesar 9,87. Kemampuan membilang sudah berkembang sangat baik (BSB). Kemampuan menulis rata-rata sebesar 9,53 dan berada dalam kriteria berkembang sangat baik. Selanjutnya kemampuan penjumlahan 9,25 dan kemampuan pengurangan rata-rata sebesar 9,08 dan berada dalam kriteria berkembang sangat baik (BSB).
\end{abstract}

Kata kunci: Kemampuan Berhitung Permulaan, Membilang, Menulis, Penjumlahan, Pengurangan 


\section{PENDAHULUAN}

Anak usia dini berada pada masa keemasan. Dimana masa ini anak mudah dalam menerima stimulus dari lingkungannya. Menurut Montesori (dalam Sujiono, 2012, hlm.54) mengatakan bahwa usia keemasan merupakan usia dimana anak mulai peka untuk menerima berbagai rangsangan dan berbagai upaya pendidikan dari lingkungannya baik itu disengaja maupun tidak disengaja. Berbagai aspek perkembangan sebaiknya dioptimalkan, agar dimasa yang akan datang anak mampu beradaptasi dengan dunia barunya. Berbagai aspek perkembangan sangat diperhatikan karena pendidikan anak usia dini ditujukan agar anak dapat mengembangkan potensinya sejak dini. Adapun aspek perkembangan di taman kanak-kanak antara lain bahasa, kognitif, sosial-emosional,fisik-motorik, moral agama dan seni. Aspek perkembangan kognitif lebih menekankan pada proses berpikir anak. Selain itu juga dapat juga dimaknai sebagai kemampuan untuk memecahkan masalah. Perkembangan kognitif salah satunya yaitu melalui kegiatan pembelajaran matematika seperti berhitung, seriasi, geometri, mencocokan, dan waktu. Pembelajaran matematika pada pendidikan formal maupun nonformal sudah sering dilaksanakan. Berhitung merupakan bagian dari matematika yang diperlukan untuk menumbuhkembangkan keterampilan berhitung yang sangat diperlukan dalam kehidupan sehari-hari, terutama konsep bilangan yang merupakan dasar bagi pengembangan kemampuan matematika maupun kesiapan untuk mengikuti kemampuan dasar (Depdiknas, 2007, hlm.1).

Kemampuan berhitung ini sangat dibutuhkan oleh anak usia dini karena ditujukan untuk menstimulasi kemampuan berpikir serta memiliki kesiapan untuk belajar matematika pada tahap yang lebih tinggi lagi. Hal tersebut sejalan dengan pendapat Floyd,dkk (dalam Reid, 2016,hlm.1) yang menyatakan bahwa "understanding the importance and development of preschoolers'numeracy skill is fundamental for those involved in early years education so they can support and encourage children to develop their skills in early learning contexts, and provide appropriate school-entry and learning”. Memahami pentingnya dan perkembangan keterampilan berhitung bagi anak prasekolah adalah hal yang fundamental bagi yang terlibat dalam pendidikan sejak dini sehingga dapat mendukung dan mendorong anak untuk mengembangkan keterampilan mereka dalam konteks pembelajaran awal masuk sekolah. Dilapangan sekolah sudah mengenalkan membaca, menulis dan berhitung. Hal ini dikarenakan tuntutan dari orang tua yang ingin anaknya masuk sekolah dasar sudah mampu menguasai konsep dan keterampilan matematika.

Kegiatan berhitung pada kenyataannya sudah diberikan di Taman kanak - kanak terutama anak di kelas B yang usia 5-6 karena dipersiapkan untuk memasuki sekolah dasar. Selain itu, dilapangan beberapa Sekolah Dasar mengeluarkan ketentuan bahwa anak yang mendaftar sudah memiliki kemampuan calistung dan ada juga sekolah yang melakukan tes seleksi untuk memasuki Sekolah Dasar tersebut.

\section{TINJAUAN PUSTAKA}

Menurut Henmon (dalam Sujiono, 2011, hlm. 1.14) kognitif dan pengetahuan disebut intelegensi. Berdasarkan pemaparan diatas maka perkembangan kognitif adalah daya seseorang untuk melakukan sesuatu seperti aktivitas. Piaget mengatakan bahwa perkembangan kognitif anak berasal dari kematangan biologi, interaksi dengan lingkungan, dan temuan spontan mereka tentang temuan itu. Piaget (dalam Beaty, 2013, hlm.270) membagi pengetahuan anak dalam tiga kategori, yaitu pengetahuan fisik, pengetahuan logis-matematis dan pengetahuan sosial.

Pada dasarnya perkembangan kognitif dimaksudkan agar anak dapat mengekplorasi terhadap dunia sekitar melalui pancaindra sehingga anak mampu mendapatkan 
pengetahuannya sendiri sehingga anak dapat melangsungkan kehidupannya. Adapun yang merupakan proses kognisi meliputi persepsi, ingatan, pikiran, simbol, penalaran, dan pemecahan masalah. Berdasarkan hal itu,piaget berpendapat bahwa pentingnya guru mengembangkan kognitif anak adalah:

a) Agar anak mampu mengembangkan daya persepsinya melalui apa yang dilihat, dirasakan, didengar sehingga anak memiliki pemahaman yang utuh;

b) Melatih ingatan anak terhadap semua yang pernah dialami anak;

c) Agar anak mampu mengembangkan pemikirannya dalam rangka menghubungkan satu peristiwa dengan peristiwa lainnya;

d) Agar anak mampu memahani simbol yang tersebar didunia;

e) Agar anak mampu melakukan penalaran, baik yang secara alamiah maupun melalui proses ilmiah;

f) Agar anak mampu memecahkan persoalan hidup yang dihadapi. (Susanto, 2014, hlm. 48).

Piaget berpendapat bahwa tahapan perkembangan kognitif semua anak sama dengan tahapan yang sama. Tahapan yang dimaksud piaget (dalam Morrison, 2015, hlm. 246-252) adalah sebagai berikut:

1) Tahap sensorimotorik (sejak lahir sampai 2 tahun). Tahap ini anak menggunakan indra serta refleks motorik mereka.

2) Tahap Praoperasional (usia 2 tahun sampai 7 tahun). Adapun karakteristik tahap ini adalah anak bergantung pada representasi menggunakan bahan konkret serta egosentris.

3) Tahap operasional konkret (usia 7 sampai 12 tahun). Anak pada tahap ini, mulai menggunakan gambaran mental dan simbol- simbol selama mereka berpikir dan dapat membalikan operasi-operasinya.
4) Tahap operasional formal (usia 11 tahun sampai dewasa). Pada tahap ini gaya berpikirnya melibatkan penggunaan operasional logika dan menggunakannya secara abstrak.

Menurut pemaparan diatas bahwa anak usia 5-6 tahun kelompok B termasuk pada tahap praoperasional. Dimana anak pada tahap ini belajar menggunakan bahan atau benda yang konkret. Ciri lainnya pada tahap ini adalah anak berada tahap egosentris. Pada tahap ini anak harus mendapat stimulasi yang baik dari lingkungan. Banyak faktor yang mempengaruhi perkembangan kognitif . Adapun faktor yang mempengaruhi perkembangan kognitif adalah:

(a) Faktor hereditas/keturunan. Teori hereditas dipelopori oleh schopenhauer yang berpendapat bahwa setiap orang lahir memiliki potensi masing-masing yang tidak dipengaruhi oleh lingkungan. Menurut Lehrin, Lindzey dan spuhier berpendapat bahwa taraf intelegensi $75-80 \%$ merupakan warisan atau faktor keturunan.

(b) Faktor lingkungan. Teori lingkungan dipelopori oleh John Locke. Menurut John Locke (dalam Soetjiningsih, 2012, hlm. 24) menyatakan bahwa perkembagan individu dimungkinkan dan ditentukan oleh lingkungan. Selain itu, manusia dilahirkan bagaikan kertas putih yang belum ada tulisan dan noda sedikitpun. Teori ini disebut dengan teori tabula rasa. Intelegensi seseorang sangat ditentukan oleh lingkungan hidupnya.

(c) Faktor kematangan. Dikatakan matang yaitu ketika setiap organ tubuh sudah sanggup menjalankan fungsinya masing-masing.

(d) Faktor pembentukan. Pembentukan adalah segala keadaan diluar diri seseorang yang dapat 
mempengaruhi intelegensi. Pembentukan ini dapat dilakukan secara sengaja maupun tidak sengaja.

(e) Faktor minat dan bakat. Minat mengarahkan perbuatan kepada suatu tujuan sehingga mendorong seseorang untuk lebih giat. Sedangkan bakat adalah adalah kemampuan bawaan yang masih perlu dikembangkan.

(f) Faktor kebebasan. Kebebasan yaitu keleluasaan manusia untuk untuk berpikir divergen atau menyebar. Maksudnya manusia dapat memilih metode tertentu untuk memecahkan masalahnya.

Faktor perkembangan kognitif anak dipengaruhi oleh faktor internal dan eksternal. Faktor internal seperti keturunan, minat, bakat dan kebebasan. Selain itu faktor eksternal yaitu faktor lingkungan. Menurut Lefevre,dkk (dalam Reid, 2016, hlm. 8) yaitu: "Parents positively influence their preschool child's math achievement when they engage in direct (e.g. teaching their children the numbers words and counting and indirect (e.g. integrating numeracy into everyday tasks such as cooking) numeracy practices with their child at home". Maksudnya adalah orang tua yang positif mempengaruhi prestasi matematika anak prasekolah ketika mereka terlibat langsung (misalnya mengajar anakanak jumlah kata dan terus menghitung) dan tidak secara langsung (misalnya mengintegrasikan menghitung dalam kehidupan sehari-hari ketika memasak) praktik berhitung dengan anak mereka dirumah. Menurut piaget (dalam Beatty, 2005, hlm. 8) mengatakan bahwa :

"Children are born with innate cognitive structures that are programed to emerge in sequence as the child develops and that cognitive skills require relatively litte environmental input in order to emerge".

Maksudnya adalah anak-anak dilahirkan dengan struktur kognitif bawaan yang diprogram untuk muncul secara berurutan saat anak berkembang dan keterampilan kognitifnya memerlukan masukan dari lingkungan agar bisa muncul. Selain itu menurut balfand, dkk (dalam MacDonal, 2015, hlm.86 ) mengatakan bahwa :

"Many other studies with the general agreement that all children in their early childhood years are capable of accessing powerfull mathematical ideas and they should be give the opportunity to access these ideas through high quality child-centred activities in their homes, communities, and prior-to-school setting”.

Howard gardner (dalam Suyadi dan Dahlia, 2014, hlm.83) mengenalkan ada 9 kecerdasan jamak, yaitu kecerdasan verballinguistik, logis-matematis, visual, spasial, musik, intrapersonal, interpersonal, kinestetik, naturalis dan eksistensial. Matematika termasuk kedalam kedalam kecerdasan logismatematis. Kecerdasan matematis-logis adalah kemampuan menggunakan nama bilangan dengan baik. (Amstrong,2003, hlm.3). Adapun dimensi dan indikator kecerdasan jamak Anak usia dini (yus, 2011, hlm. 24) yaitu sebagaimana pada tabel berikut ini:

Tabel 1. Dimensi dan Indikator kecerdasan

Jamak anak usia dini

\begin{tabular}{|c|c|}
\hline Dimensi & Dimensi \\
\hline \multirow[t]{5}{*}{$\begin{array}{c}\text { Logika } \\
\text { Matematika }\end{array}$} & $\begin{array}{l}\text { 1. Mengidentifikasi warna } \\
\text { benda-benda disekitarnya } \\
\text { (perabot,daun,batang, dan } \\
\text { lain-lain) }\end{array}$ \\
\hline & $\begin{array}{l}\text { 2. Memasangkan gambar } \\
\text { benda dengan } \\
\text { fungsi/kegunaannya. }\end{array}$ \\
\hline & $\begin{array}{l}\text { 3. Mengurutkan benda } \\
\text { berdasarkan ukuran, warna }\end{array}$ \\
\hline & 4. Menghitung angka satuan \\
\hline & $\begin{array}{l}\text { 5. Mengidentifikasi bentuk- } \\
\text { bentuk geometri dalam } \\
\text { satu benda. }\end{array}$ \\
\hline
\end{tabular}

Bryant and Nunes (dalam Aunio, 2015. hlm. 4) mengemukakan bahwa "have suggested that 
the basis for children's early mathematical development is logical thinking, the teaching of conventional counting systems and a meaningful context for learning mathematics". Bryant and Nunes mengatakan bahwa dasar dari perkembangan matematika awal anak adalah pemikiran logis, pengajaran perhitungan secara konvensional dan sesuai konteks untuk belajar matematika angka awal, termasuk kemampuan untuk beroperasi dengan urutan jumlah kata dan perhitungan yang dikombinasikan dengan kemampuan berpikir matematis logis merupakan inti dari perkembangan matematika di masa kecil.

Setiap orang dilahirkan memiliki potensi masing-masing. Istilah kemampuan dapat didefinisikan berbagai arti tergantung sudut pandang seseorang. Menurut Munandar (dalam Susanto, 2014, hlm. 97) kemampuan adalah daya untuk melakukan sesuatu yang merupakan dari hasil pembawaan dan latihan. Jadi menurut Munandar bahwa kemampuan ini merupakan pembawaan sejak lahir kemudian dipermatang dengan latihan. Kemampuan berhitung ini perlu diajarkan sejak dini dengan berbagai media dan metode yang tepat jangan sampai malah merusak perkembangan anak. Menurut fatimah (Maerina, 2014, hlm.18) menyatakan bahwa pendekatan dengan menggunakan materi konkret dan gambar harus secara intensif dilakukan ditingkat awal, sebelum anak selanjutnya memasuki angka abstrak. Menurut Hariwijaya (dalam Martiana, 2014, hlm. 39-40) berhitung merupakan bagian dari komponen mengenai konsep bilangan,lambang bilangan. Anak diharapkan mampu mengenal konsep,bilangan dan lambang bilangan sehingga mampu berhitung yang baik dan benar. Berhitung sangat dengan kehidupan sehari-hari disekitar tempat tinggal, sekolah,tempat umum dan dimana saja.

Prinsip-prinsip dalam berhitung permulaan untuk anak usia dini dikenalkan melalui melalui permainan berhitung. Ada beberapa prinsip mendasar yang perlu dipahami dalam menerapkan permainan berhitung, yaitu: a) permainan berhitung diberikan secara bertahap. Diawali dengan menghitung benda yang ada lingkungan sekitar; b) pengetahuan dan keterampilan diberikan secara bertahap berdasarkan tingkat kesukarannya, misalnya dari konkrit ke abstrak, dari yang sederhana ke yang kompleks; c) anak berpartisipasi aktif dan adanya rangsangan untuk menyelesaikan masalahnya sendiri; d) suasana yang menyenangkan; e) bahasa yang digunakan yaitu bahasa yang sederhana dan mengambil contoh dari lingkungan sekitar anak; f) anak dikelompokana berdasarkan tahapan berhitung, yaitu tahap konsep, tahap masa transisi dan lambang; g) evaluasi hasil perkembangan dari awal sampai akhir kegiatan. (Depdiknas, 2007, hlm.2).

Piaget mengatakan bahwa untuk meningkatkan perkembangan mental anak ke tahap yang lebih tinggi dapat dilakukan dengan memperkaya pengalaman anak terutama pengalaman kongkrit, karena dasar perkembangan mental adalah melalui pengalaman- pengalaman aktif dengan menggunakan benda yang ada disekitarnya. Sejalan dengan hal tersebut berhitung di Taman kanak-kanak seyogyanya dilakukan tiga tahap, yaitu sebagai berikut:

1) Penguasaan konsep

Pemahaman dan pengertian tentang sesuatu dengan menggunakan benda kongkrit.

2) Masa transisi/peralihan

Proses berpikir yang merupakan masa peralihan dari pemahaman kongkrit menuju pengenalan lambang yang abstrak, dimana benda kongkrit itu masih ada dan mulai dikenalkan lambangnya.

3) Lambang.

Merupakan visualisasi dari berbagai konsep, misalnya lambang 7 untuk menggambarkan konsep bilangan tujuh. (Depdiknas, 2007, hlm.6).

Menurut Hurlock (dalam Susanto, 2011, hlm.107) mengatakan bahwa seiring perkembangan pemahaman bilangan permulaan ini, menyatakan bahwa konsep yang pertama dipahami oleh anak sejalan dengan bertambahnya pengalaman anak, diantaranya konsep bilangan. konsep bilangan ini 
berhubungan dengan kata-kata. Pada saat anak memasuki taman kanak-kanak anak umumnya pemahaman konsep bilangan akan berkembang dengan cepat sampai pada peningkatan ke tahap pengertian mengenai jumlah. Menurut Syverson (2008, hlm. 4) mengatakan bahwa:

"Number and operations are used for counting, adding, and subtracting. Young children learn about numbers and operations as they help set the table and pass out one glass for each person, count how many cookies are on the plate, then eat one and count how many are left".

Angka dan operasi dapat digunkan untuk menghitung, menjumlahkan dan mengurangi. Anak kecil belajar tentang angka dan operasi untuk membantu mereka menyiapkan meja dan mengatur masing-masing gelas, menghitung berapa banyak kue diatas piring, kemudian dimakan satu dan menghitung berapa kue yang tersisa.

Adapun tingkatan pencapaian perkembangan Anak usia 5-6 tahun yang berhubungan dengan berhitung yaitu:

Tabel 2. Tingkat Pencapaian perkembangan Anak

\begin{tabular}{ll}
\hline $\begin{array}{l}\text { Lingkup } \\
\text { perkembangan }\end{array}$ & Usia 5-6 Tahun \\
\hline $\begin{array}{ll}\text { Kognitif } \\
\text { (Berpikir }\end{array}$ & 1. Menyebutkan \\
simbolik) & $1-10$ \\
& Menggunakan \\
& lambang bilangan \\
& untuk menghitung \\
\hline Menurut Piaget & (dalam Maerina,
\end{tabular}

2014,hlm.15) berpendapat bahwa anak taman kanak-kanak berada fase perkembangan praoperasional menuju konkret. Anak pada fase ini belajar terbaik melalui benda nyata. Benda yang ada disekitar anak dapat digunakan untuk berhitung. Benda yang dapat digunakan untuk melatih anak berhitung seperti manik-manik, biji, permen, atau bendabenda untuk permainan.

Kemampuan yang dinilai dalam kemampuan berhitung ini adalah kemampuan membilang angka 1-10, menulis angka 1-10, penjumlahan dan pengurangan. Geary (1994. hlm. 14) mengatakan bahwa " child must learn to create a one-to-one correspondence between number names and counted items, such that each item is assigned only a single number name. The child must also learn to order the number names in the correct sequence (i.e., one, two,three,..) and come to understand that the last number named in the count,that is the cardinal number, holds special meaning-it represents the total number of counted items.

Menurut Cross (2009, hlm. 129) bahwa “ 1-to-1 Counting Correspondences:When children do begin counting, they must use oneto-one counting correspondences so that each object is paired with exaclty one number word." Maksudnya adalah ketika anak akan mulai menghitung, mereka harus menggunakan korespondensi satu-satu sehingga masing-masing benda di pasangankan tepat satu angka dengan dengan satu kata.

Selanjutnya kemampuan menulis angka 110. Anak mampu menulis angka sesuai dengan jumlah gambar. Cross (2009, hlm. 129) menyatakan bahwa : "written number symbols: children learn written number symbols through having such symbols around them named by their number word". Maksudnya adalah anak belajar menulis simbol angka melalui simbolsimbol seperti disekitar mereka dinamai oleh mereka (seperti itu adalah dua). Jadi mengenalkan angka dua dengan benda yang ada disekitarnya. Selanjutnya penjumlahan dan pengurangan. Menurut Cross (2009, hlm. 130) bahwa "kindergartners show comparing situasi with objects or in a drawing and match or count to find out which is more and which is less for two number $\leq 10$. Gunakan perhitungan kardinal untuk memecahkan situasi dengan objek atau menggambar dan masalah menghitung dengan total $\leq 10$. Pada penjumlahan dikenalkan pula tanda + untuk penjumlahan dan tanda - untuk pengurangan. Karena anak perlu pengalaman yang lebih sebelum memasuki sekolah dasar dan sebelum tanda tersebut digunakan dalam persamaan.

Menurut Baroody (dalam Cross, 2009, hlm 153) bahwa "Counting Down ti subtract is difficult, and make many erros at it". 
Pengurangan itu sulit sehingga banyak anak yang mengalami kesalahan. Berhitung mundur lebih sulit dibandingkan berhitung maju. Selain itu biasanya umur 2,3, dan 4 tahun menghitung selalu berawal dari 1 tidak dapat sembarang angka. Mereka akan menghirung mulai dari satu tidak bisa seperti $5+2=7$ (lima kemudian menghitung bagian kedua langsung enam,tujuh melainkan berawal dari satu lagi.

\section{METODE PENELITIAN}

Menurut sugiyono (2012, hlm.12) metode deskriftif adalah metode yang digunakan dalam penelitian untuk menggambarkan atau mendeskripsikan hasil penelitian dari suatu keadaan atau kondisi tertentu tetapi tidak digunakan untuk membuat kesimpulan yang lebih luas. Jadi metode deskriptif adalah metode yang bertujuan mengungkapkan atau mendeskripsikan sesuatu yang sedang terjadi. Jenis penelitian ini yaitu survey. Survey digunakan untuk mendapatkan data dari tempat tertentu yang alamiah (bukan buatan), tetapi peneliti melakukan dalam pengumpulan data misalnya dengan mengedarkan kuesioner, angket, test, wawancara dll (perlakuan tidak seperti dalam eksperimen) (sugiyono, 2012, hlm.12). Salah satu tujuan dari penelitian survey adalah untuk mendeskripsikan atau menggambarkan suatu gejala maupun keadaan. Disini penelitian ini mengetahui kemampuan berhitung anak kelompok B se-kelurahan Lengkongsari. Di kelurahan tersebut terdapat tiga taman kanakkanak,yaitu TK Ibadurrahman, TK perwari 2, dan TK nurul huda. Populasi dari penelitian ini adalah TK se-kelurahan Lengkongsari Kota Tasikmalaya.

Dalam penelitian ini, teknik pengambilan sampel dilakukan dengan cara nonprobability sampling yaitu Purposive sample adalah yaitu penentuan sampel berdasarkan beberapa pertimbangan (Arikunto, 2013, hlm.183). Sample penelitian ini yaitu anak TK kelompok B. Menurut Arikunto (2013, hlm. 112) mengatakan bahwa jika subjek penelitiannya kurang dari seratus maka sunjek yang digunakan semuannya sehingga penelitiannya populasi. Akan tetapi jika jumlah subjeknya besar dapat diambil $10-15 \%$ atau $15-25 \%$ atau lebih. Sedangkan menurut Roscoe (dalam Sugiyono, 2013, hlm. 131) ukuran sampel yang layak dalam sebuah penelitian adalah 30 sampai dengan 500. Jumlah keseluruhan populasi penelitian ini adalah 140 anak. Maka sampel diambil 32\% dari keseluruhan populasi maka jumlah sampel dalam penelitian ini berjumlah 45 anak dari tiga sekolah.

Instrumen penelitian adalah suatu alat yang digunakan mengukur fenomena alam maupun sosial yang diamati (Sugiyono, 2012,hlm.148). Instrumen yang digunakan adalah lembar observasi, test, wawancara, studi dokumentasi. Data yang digunakan dalam penelitian ini adalah data yang bersifat kuantitatif. Sedangkan sumber data yang digunakan dalam penelitian ini berdasarkan sample purposive. Jenis validitas yang digunakan dalam penelitian ini yaitu validitas konstrak. Validitas konstrak ini menggunakan pendapat dari ahli (judgment expert). Kemudian dilakukan uji validitas eksternal. Menurut Sugiyono (2012, hlm.183) validitas eksternal instrumen diuji dengan cara membandingkan (untuk mencari kesamaan) antara kriteria yang ada pada instrumen dengan fakta-fakta empiris yang terjadi dilapangan. Validitas eksternal kemampuan berhitung permulaan anak kelompok B TK Pertiwi DWP. Pengujian realiabilitas instrumen setelah diuji cobakan yaitu menggunakan rumus $\mathrm{KR}$ 21. Diketahui bahwa reliabilitas dari instrumen penelitian yaitu sebesar 0,72 dan mendekati nilai 1 maka instrumen dapat dinyatakan reliabel.

Teknik yang digunakan dalam penelitian ini yaitu observasi, test, wawancara dan studi dokumentasi dan catatan lapangan. Dokumentasi adalah sebuah cara yang dilakukan untuk penyediaan dokumen dengan menggunakan bukti yang akurat dari pencatatan sumber informasi. Menurut Esterberg (dalam Sugiyono, 2012. hlm. 319320) terdapat beberapa macam wawancara, yaitu wawancara terstruktur, semiterstruktur 
dan tidak terstruktur. Dalam penelitian ini mengunakan wawancara semi terstruktur. Dimana wawancara semi terstruktur adalah peneliti tetap membawa pedoman wawancara akan tetapi pertanyaan yang diajukan secara garis besar.

Teknik analisis dalam penelitian menggunakan statistik. Terdapat dua macam statistik yang digunakan dalam penelitian yaitu statistik deskriftif dan statistik inferensial. Dalam penelitian ini menggunakan statistik deskriptif. Statistik deskriftif adalah statistik yang digunakan untuk menganalisis data dengan cara mendeskripsikan atau menggambarkan data yang telah terkumpul sebagaimana adanya tanpa bermaksud membuat kesimpulan yang berlaku untuk umum atau generalisasi. (sugiyono,2012, hlm. 207-208). Skor yang dicari dalam penelitian ini adalah sebagai berikut;

1. Skor total adalah jumlah keseluruhan skor yang diperoleh anak.

2. Rata-rata nilai yang diperoleh anak.

3. Mencari rata-rata setiap indikator dan rata-rata kemampuan berhitung.

Skor yang diperoleh oleh anak digunakan untuk menarik kesimpulan. Kesimpulan tersebut diambil berdasarkan kriteria dasar menurut Acep Yoni (dalam Maerina, 2014, hlm. 34) yang telah disesuaikan dengan kriteria yang perkembangan yang berlaku di taman kanak-kanak.. Kriteria tersebut dapat dilihat pada Tabel 3 Yaitu kreiteria perolehan skor rata-rata kemampuan berhitung permulaan, sebagai berikut:

Tabel 3. Kriteria Kemampuan Berhitung menurut Acep Yoni kemampuan membilang ini peneliti menggunakan benda yang nyata bagi anak. Benda yang digunakan adalah pensil. Pensil sering ditemukan oleh anak terutama disekolah. Kemampuan membilang ini jadi anak mampu menunjukan jumlah benda dengan angka yang disebutkan. Seperti angka lima dengan menunjukan lima pensil. Di TK Perwari 2 anak-anak sudah mampu menunjukan benda dengan tepat dan tanpa dibantu. Hanya ada seorang anak yang mampu menyebutkan angka akan tetapi untuk menunjukan banyaknya pensil sesuai angka masih memerlukan bantuan dari temannya. Kemampuan menyebutkan angka dan menunjukan jumlah benda yang benar dari satu sampai sepuluh anak tersebut hanya mampu sampai angka lima. Angka enam dan seterusnya anak masih memerlukan bantuan. Selanjutnya TK Ibadurrohman kemampaun membilang di TK ini juga sudah berkembang sangat baik hanya ada satu anak yang masih memerlukan bantuan menunjukan banyaknya pensil sesuai angka. Anak tersebut terkendala menunjukan banyaknya pensil pada angka lima sampai dengan sepuluh. TK Nurul Huda kemampuan membilang angka satu sampai dengan sepuluh sudah berkembang sangat baik. Dari lima belas anak hanya satu anak yang memerlukan bantuan menunjukan benda sesuai angka. Anak tersebut juga terkendala menunjukan banyaknya benda sesuai angka dari angka lima sampai dengan sepuluh.

Kemampuan membilang angka 110 rata-rata yang diperoleh oleh masingmasing TK berbeda. Masing-masing TK terdiri dari 15 orang anak. TK Perwari 2

\begin{tabular}{lll}
\hline No & Kriteria menurut Acep Yoni & N \\
\hline $\mathbf{1}$ & Sangat Baik & 7,50 \\
$\mathbf{2}$ & Baik & 5,00 \\
$\mathbf{3}$ & Cukup & 2,50 \\
$\mathbf{4}$ & Kurang & 0 \\
\hline
\end{tabular}

HASIL DAN PEMBAHASAN

Penelitian tentang berhitung permulaan salah satu indikatornya adalah kemampuan membilang angka 1-10. Pada

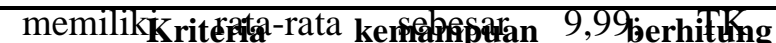
Ibadurolperamulgalmesar 9,82; dan TK Nurul

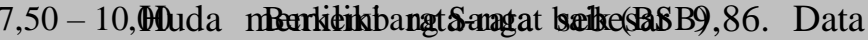

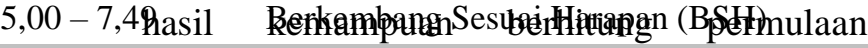

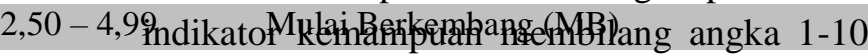
$0-2,49$ anak Bekum Berkembang (BB) Se-Kelurahan

Lengkongsari Kota Tasikmalaya terdapat 45 orang anak yang berada pada kriteria sangat baik menurut Acep Yoni atau kriteria berkembang sangat baik yaitu dengan persentase sebesar $100 \%$. Pada kriteria 
berkembang sesuai harapan, mulai berkembang dan belum berkembang tidak ada anak yang berada dalam kriteria tersebut dengan presentase yaitu $0 \%$, sehingga dapat disimpulkan bahwa kemampuan membilang angka 1-10 berada pada kriteria berkembang sangat baik (BSB) dengan persentase 100\%.

Penelitian tentang kemampuan berhitung permulaan indikator kedua yaitu kemampuan menulis angka 1-10. Kemampuan menulis ini dilihat dari lembar kerja anak yang penjumlahan dan pengurangan. Kesalahan penulisan yang anak buat selalu diulangi. Deskripsi kemampuan anak apabila memperoleh skor 0 adalah ketika anak sama sekali tidak menulis pada salah satu angka. Misalnya kemampuan menulis angka 1 anak sama sekali tidak menulis satu pun angka 1. Di TK Perwari 2 kemampuan menulis angka 1-10 sudah berkembang sangat baik. Meskipun sudah berkembang sangat baik akan tetapi skor yang diperoleh setiap anak berbeda-beda. TK Ibadurrohman kemampuan menulis angka 1-10 berkembang sangat baik semua anak. TK Nurul Huda kemampuan membilang angka 110 pun sama dengan kedua TK sebelumnya yaitu berkembang sangat baik.

Rata-rata kemampuan menulis angka 1-10 terlihat bahwa data yang diperoleh oleh masing TK berbeda. TK Perwari 2 memiliki rata-rata sebesar 9,35; TK Ibadurrohman memiliki rata-rata sebesar 9,41; dan TK Nurul Huda memiliki rata-rata sebesar 9,82. Data hasil kemampuan berhitung permulaan indikator kemampuan menulis angka 1-10 anak TK Kelompok B Se-Kelurahan Lengkongsari Kota Tasikmalaya terdapat 45 orang anak yang berada pada kriteria sangat baik menurut Acep Yoni atau kriteria berkembang sangat baik yaitu dengan persentase sebesar $100 \%$. Pada kriteria berkembang sesuai harapan, mulai berkembang dan belum berkembang tidak ada anak yang berada dalam kriteria tersebut dengan presentase yaitu $0 \%$, sehingga dapat disimpulkan bahwa kemampuan menulis angka 1-10 berada pada kriteria berkembang sangat baik (BSB) dengan persentase $100 \%$.
Penelitian tentang berhitung permulaan salah satu indikatornya adalah kemampuan penjumlahanyang hasilnya 1-10. Pada kemampuan penjumlahan ini peneliti menggunakan lembar kerja anak. Gambar yang digunakan yaitu tentang peralatan sekolah, seperti gambar buku, pensil, penggaris,pengahapus,serutan pensil. Kemampuan penjumlahan ini nak pertama menyalin angka sesuai gambar kemudian mengisi kotak kosong untuk hasilnya. Penyampaian lembar kerja anak disampaikan oleh guru dikelas tersebut. Di TK Perwari 2 anak-anak sudah mampu mengerjakan penjumlahan dengan benar walaupun skor yang didapat masing-masing anak berbeda. Untuk Selanjutnya TK Ibadurrohman kemampuan penjumlahan di TK ini juga sudah berkembang sangat baik. Anak sudah mengerti tentang penjumlahan. TK Nurul Huda kemampuan penjumlahan anak dari 15 anak terdapat satu orang yang berkembang sesuai harapan dan sisanya berkembang sangat baik.

Kemampuan penjumlahan angka terlihat bahwa rata-rata yang diperoleh oleh masing-masing TK berbeda. Masing-masing TK terdiri dari 15 orang anak. TK Perwari 2 memiliki rata-rata sebesar 9,51; TK Ibadurohman sebesar 8,82; dan TK Nurul Huda memiliki rata-rata sebesar 9,42. Data hasil kemampuan berhitung permulaan indikator kemampuan penjumlahan anak TK Kelompok B Se-Kelurahan Lengkongsari Kota Tasikmalaya terdapat 43 anak yang berada pada kriteria sangat baik menurut Acep Yoni atau kriteria berkembang sangat baik yaitu dengan persentase sebesar 95,6\% dan apabila dibulatkan menjadi 96\%. Pada kriteria berkembang sesuai harapan menurut Acep Yoni sebanyak 2 anak apabila dengan presentase maka sebesar $4,4 \%$ dan dibulatkan menjadi $4 \%$. Dan kriteria mulai berkembang dan belum berkembang dengan persentase yaitu $0 \%$. Sehingga dapat disimpulkan bahwa kemampuan penjumlahan berada pada kriteria berkembang sangat baik (BSB) dengan persentase $95,6 \%$. 
Penelitian tentang berhitung permulaan salah satu indikatornya adalah kemampuan pengurangan yang hasilnya 110. Untuk mengukur kemampuan pengurangan peneliti menggunakan lembar kerja anak. Lembar kerja anak ini menggunakan gambar. Gambar yang digunakan adalah gambar yang didunia nyata anak sering lihat dan menggunakannya. Gambar yang digunakan yaitu gambar tentang peralatan sekolah, seperti buku, pensil, serutan, penghapus dan penggaris. Di TK Perwari 2 kemampuan pengurangan anak-anak sudah mampu melakukan pengurangan. Akan tetapi masih ada yang menganggap pengurangan itu penjumlahan. Meskipun demikian kemampuan pengurangan anak berada kriteria berkembang sangat baik. TK Ibadurrohman kemampuan pengurangan anak sudah mampu mengerjakan dengan benar tentang pengurangan. Kemampuan pengurangan ini berada pada kriteria berkembang sangat baik. TK Nurul Huda sudah mampu mengerjakan pengurangan dengan baik. Kegiatan pengurangan dilaksanakan secara klasikal. Kemampuan pengurangan di TK Nurul Huda sudah sangat baik anak-anak mampu mengerjakan pengurangan dengan benar dan sudah mengerti perintah.

Kemampuan pengurangan yang hasilnya 1-10 terlihat bahwa rata-rata yang diperoleh oleh masing-masing TK berbeda. Masing-masing TK terdiri dari 15 orang anak. TK Perwari 2 memiliki rata-rata sebesar 9,27; TK Ibadurohman sebesar 8,40; dan TK Nurul Huda memiliki rata-rata sebesar 9,56. Data hasil kemampuan berhitung permulaan indikator kemampuan pengurangan anak TK Kelompok B Se-Kelurahan Lengkongsari Kota Tasikmalaya terdapat 41 orang anak yang berada pada kriteria sangat baik menurut Acep Yoni atau kriteria berkembang sangat baik yaitu dengan persentase sebesar 91,1\% dibulatkan menjadi 91\%. Pada kriteria berkembang sesuai harapan terdapat orang anak yang berada pada kriteria menurut Acep
Yoni apabila di persentasekan maka sebesar $8,9 \%$ dibulatkan menjadi $9 \%$. Sedangkan pada kriteria mulai berkembang dan belum berkembang tidak ada anak yang berada pada kriteria tersebut.

Berdasarkan data yang telah diperoleh tentang kemampuan berhitung permulaan yang meliputi kemampuan berhitung permulaan di TK Se-Kelurahan Lengkongsari Kota Tasikmalaya berikut ini disajikan rekapitulasi hasil keseluruhan kemampuan berhitung permulaan pada Tabel 4. sebagai berikut:

Tabel 4. Rekapitulasi Data Kemampuan berhitung permulaan TK Kelompok B Se-Kelurahan Lengkongsari Kota Tasikmalaya

\begin{tabular}{lccr}
\hline \multirow{2}{*}{ Nama TK } & \multicolumn{3}{c}{ Rata-rata Kemampuan berh } \\
\cline { 2 - 4 } TK Perwari 2 & Membilang & Menulis & Penjum \\
TK & 9,90 & 9,35 & 9,5 \\
Ibadurrohman & 9,85 & 9,41 & 8,8 \\
TK Nurul Huda & 9,86 & 9,82 & 9,4 \\
Total skor & 29,61 & 28,58 & 27,7 \\
Rata-rata & 9,87 & 9,53 & 9,2 \\
\hline Berdasarkan & tabel & 4 dapat & dilihat
\end{tabular}

setiap TK memiliki nilai rata-rata kemampaun berhitung permulaan yang berbeda-beda. TK Nurul Huda memiliki nilai rata-rata tertinggi dibanding dengan TK yang lain yaitu sebesar 9,70. Apabila tabel 4 ditunjukan dalam diagram batang, maka akan tampak pada gambar 1 sebagai berikut:

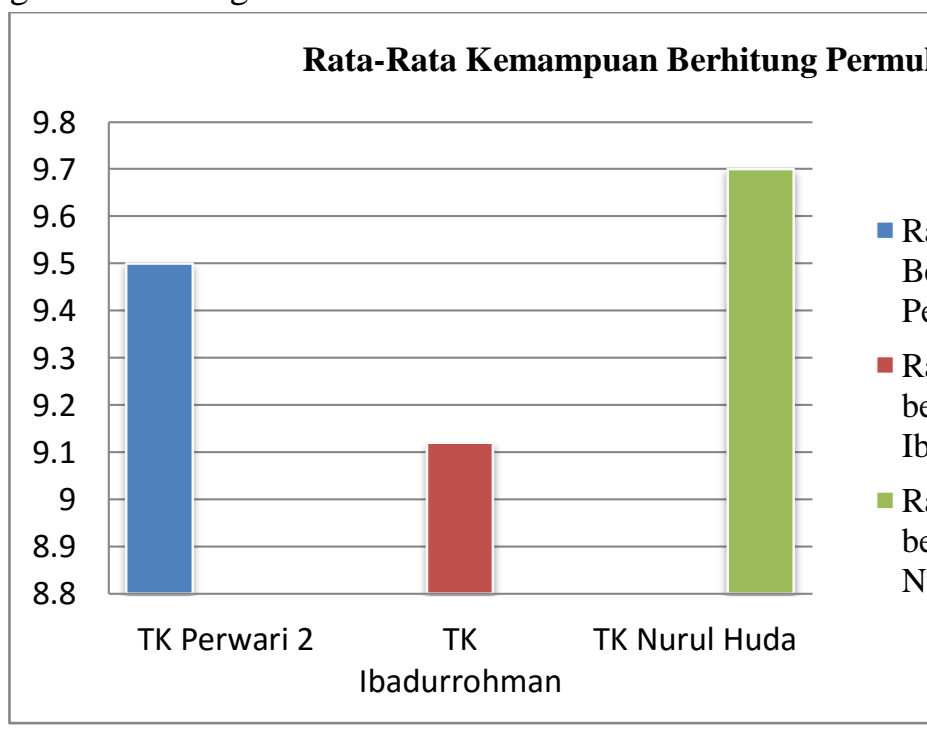

Gambar 1: Diagram Rata -Rata Kemampuan Berhitung Permulaan

Se-Kelurahan Lengkongsari Kota Tasikmalaya 
Berdasarkan tabel 4 bahwa setiap indikator kemampuan berhitung permulaan anak TK kelompok B Se-Kelurahan Lengkongsari Kota Tasikmalaya yaitu kemampuan membilang menunjukan rata-rata sebesar 9,87. Kemampuan menulis angka 1-10 menunjukan rata-rata sebesar 9,53. Kemampuan penjumlahan menunjukan ratarata sebesar 9,25 dan kemampaun pengurangan menunjukan rata-rata sebesar 9,08. Apabila setiap indikator tersebut di tunujukan dalam diagram batang maka akan tampak pada gambar 2 sebagai berikut:

Rata-rata kemampuan berhitung permulaan setiap indikator

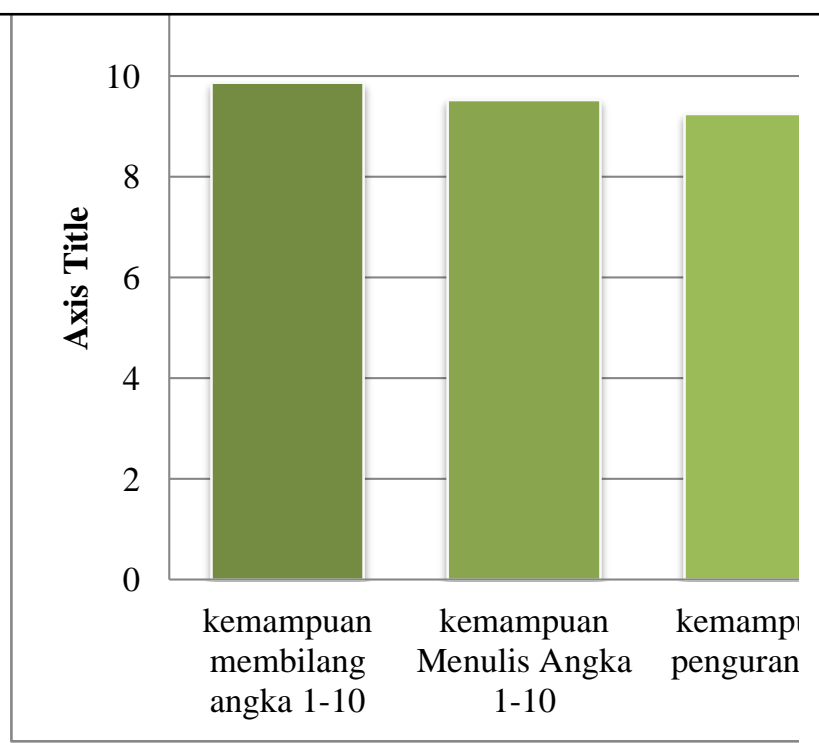

Gambar 2: Diagram Rata-Rata Kemampuan Berhitung Perrmulaan Setiap Indikator

Berdasarkan data skor yang sudah diperoleh dalam kemampuan berhitung permulaan dengan jumlah anak 45 digunakan untuk menarik kesimpulan. Kesimpulan tersebut diambil berdasarkan kriteria dasar menurut Acep Yoni (dalam Maerina, 2014, hlm. 34) yang telah disesuaikan dengan kriteria perkembangan anak. Apabila data yang diperoleh dipaparkan dalam Tabel 5 tentang kriteria kemampuan berhitung sebagai berikut:

Tabel 5. Kriteria Kemampuan Berhitung

Permulaan Se-Kelurahan Lengkongsari

$\begin{array}{ll}\text { No } & \text { Kriteria } \\ & \text { menurut } \\ & \text { Acep Yoni }\end{array}$

\begin{tabular}{|llll|}
\hline $\mathbf{1}$ & Sangat Baik & $7,50-10,00$ & $\begin{array}{l}\text { Berkembang S } \\
(\mathrm{BSB})\end{array}$ \\
\hline $\mathbf{2}$ & Baik & $5,00-7,49$ & $\begin{array}{l}\text { Berkembang } \\
\text { Harapan (BSH) }\end{array}$ \\
\hline $\mathbf{3}$ & Cukup & $2,50-4,99$ & Mulai Berkemb \\
\hline $\mathbf{4}$ & Kurang & $0-2,49$ & Belum Berkemb \\
\hline Jumlah & & \\
\hline
\end{tabular}

Berdasarkan pemaparan data pada tabel 5 yaitu pemaparan data hasil kemampuan berhitung permulaan anak TK Kelompok B SeKelurahan Lengkongsari Kota Yogyakarta aka dapat disimpulkan bahwa kemampuan rhitung permulaan anak sudah berada dalam kriteria berkembang sangat baik, apabila ditampilkan dalam diagram batang maka akan tampak seperti pada gambar 3 sebagai berikut:

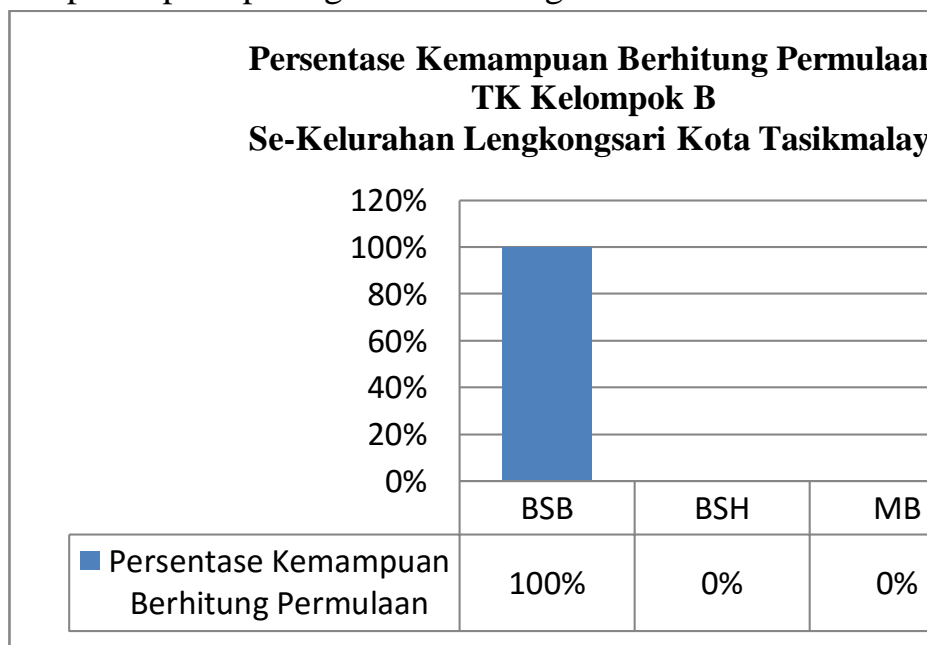

Gambar 3: Diagram kemampuan berhitung permulaan TK Kelompok B Se-Kelurahan Lengkongsari Kota Tasikmalaya Wawancara terhadap guru TK Perwari 2 dilaksanakan pada hari kamis tanggal $18 \mathrm{Mei}$ 2017. Diketahui dari hasil wawancara bahwa mengajarkan kegiatan berhitung disekolah ini terutama kelompok B menggunakan kartu angka dan benda-benda nyata. Kartu angka yang digunakan misal dari angka 1-10 dibuat untuk masing-masing anak. Sehingga tidak berebut. Selain itu menggunakan benda nyata seperti buah-buahan. Guru ke sekolah membawa buah asli seperti salak. Guru Kriteria biakemampupenedamglath terlebisentastahulu berhitungpeisahodyaa +2 menggunakan salak. Kemudian dihitung bersama-sama jumlahnya berapa $2+2$. Selain media diatas guru juga menggunakan 
majalah anak. Tidak ada kendala dalam mengajarkan berhitung, karena selain belajar disekolah ada juga anak yang belajar dengan orang tuannya dirumah dan ada juga yang mengikuti les di luar sekolah.

Data hasil wawancara dengan guru TK ibadurohman bahwa mengajarkan kegiatan berhitung yaitu menggunakan jari dan lembar kerja anak serta media yang ada disekolah. Misal dari media yang ada disekolah menggunakan alat main anak untuk dihitung. Selain itu suka dengan menghitung jumlah teman. Tidak ada kendala dalam mengajarkan berhitung disekolah. Rata-rata anak cepat dalam belajar berhitung. Selain itu ada beberapa anak yang memang selalu belajar dengan orang tua dirumah dan ada beberapa yang ikut les.

Data hasil wawacara yang di dapat dari guru TK Nurul Huda bahwa mengajarkan berhitung yaitu dengan media. Media yang biasanya digunakan seperti menghitung dengan jari, dengan gambar yang ada dimajalah dan menghitung benda yang ada disekitar. Selain di kegiatan inti berhitung juga sering digunakan sebelum pulang. Maksudnya anak disuruh menebak hasil dari penjumlahan atau hasil dari pengurangan siapa yang lebih dulu dapat baris paling depan. Tidak ada kendala dalam mengajarkan berhitung. Selain di sekolah ada juga anak yang mengikuti les diluar.

Kemampuan berhitung permulaan meliputi

3 aspek dan 4 indikator. Indikator yang pertama adalah membilang angka 1-10. Membilang dalam penelitian ini yaitu kemampuan anak memasangakan satu angka dengan banyaknya benda. Setiap anak-anak mempunyai kemampuan berbeda - beda. Begitu pun dengan kemampuan membilang hasil yang diperoleh pun berbeda-beda setiap anak.

Kemampuan membilang angka 1-10 menunjukan hasil yang terdapat dalam kriteria berkembang sangat baik dari 45 anak. Terdapat 3 anak yang masih memerlukan bantuan dari temannya. Anak tersebut belum mampu memasangkan dengan benar bahwa angka 5 benda yang diambilpun berjumlah 5 benda. Berarti disini kemampuan korespondensi satusatu anak belum bisa untuk angka yang lebih dari angka 5. Sebagaimana dalam Cross (2009, hlm. 129) " 1-to-1 Counting Correspondences:When children do begin counting, they must use one-to-one counting correspondences so that each object is paired with exaclty one number word". Ketika anak mulai menghitung anak harus menggunakan korespondensi satu-satu yaitu masing-masing benda dipasangkan dengan angka. Begitu pun kemampuan membilang ini kemampuan dasar anak memahami angka. Maka dari itu anak yang belum mampu menggunakan korespondensi satu-satu mendapatkan nilai yang berbeda dengan temannya. Anak-anak ketika melakukan membilang selalu memulai dari angka satu tidak bisa langsung ke sembarang angka. Misalnya pertama membilang 5 berarti anak memasangkan angka dengan lima benda. Kemudian diambil lagi dua buah pensil. Ketika orang dewasa bisa melanjutkan membilang enam dan tujuh. Anak-anak kembali ke satu menghitungnya.

Menulis dapat berupa huruf dan angka yang dibuat menggunakan pena dan yang lainnya. Kemampuan menulis anak TK Kel. B Se-Kelurahan Lengkongsari Kota Tasikmalaya dari jumlah anak 45 anak berada dalam kriteria berkembang sangat baik. Meskipun berkembang sangat baik akan tetapai nilai yang didapat setiap anak berbeda-beda. Masih terdapat beberapa kesalahan. seperti menulis angka terbalik. Dalam kemampuan menulis anak-anak menulis angka sesuai jumlah gambar. Sebagaimana dalam Cross (2009, hlm. 129) bahwa : "written number symbols: children learn written number symbols through having such symbols around them named by their number word". Maksudnya anak menulis angka dengan simbol-simbol yang ada disekitar mereka. Jadi peneliti menggunakan gambar yang sering anak temui. Kemampuan menulis ini peneliti lihat dan amati ketika anak mengerjakan penjumlahan pengurangan. Anak- 
anak melakukan kesalahan yang selalu diulang. Misalnya menulis angka 4 terbalik. Maka akan diulangi lagi pada penulisan angka 4 selanjutnya. Selain itu kemampuan menulis dipengaruhi juga oleh beberapa faktor seperti faktor kematangan dan faktor lingkungan.

Kemampuan penjumlahan sangat dipengaruhi kemampuan yang sebelumnya dimana ketika anak mendapatkan nilai penuh maka anak mampu menyalin angka sesuai gambar. Kemampuan penjumlahan 43 anak berada dalam kriteria berkembang sangat baik dan 2 orang berada dalam kriteria berkembang sesuai harapan. Kesalahan yang sering dilakukan oleh dalam penjumlahan adalah anak menyalin angka benar akan tetapi ketika hasil dari penjumlahan tersebut salah.

Kemampuan pengurangan dari semua indikator mendapat nilai rata-rata yang rendah. Kesalahan yang sering dilakukan anak adalah anak menjumlahan angkanya. Sehingga hasil didapat bukan penguranganakan tetapi hasil dari penjumlahan. Seperti pada penjumlahan angka besar seperti 10-2 $=11$. Sebagaimana menurut Baroody (dalam Cross, 2009, hlm 153) bahwa "Counting Down ti subtract is difficult, and make many erros at it". Pengurangan itu sulit sehingga banyak anak yang mengalami kesalahan. Berhitung mundur lebih sulit dibandingkan berhitung maju. Maka dari itu dari jumlah semua anak yaitu 45 anak terdapat 41 anak yang berada dalam kriteria berkembang sangat baik dan 4 orang dalam kriteria berkembang sesuai harapan.

Kemampuan berhitung permulaan anak TK Kelompok B Se-kelurahan Lengkongsari Kota Tasikmalaya dari 45 anak. Berada dalam kriteri berkembang sangat baik. Hal tersebut dipengaruhi oleh beberapa faktor. Seperti faktor Internal dan Eksternal. Diketahui bahwa beberapa anak mengikuti yang dimiliki anak. Selain les, belajar disekolah orang tua juga berperan dalam kegiatan belajar anak dirumah dan mempengaruhi kemampuan matematika. Sebagaimana menurut Menurut Lefevre,dkk (dalam Reid, 2016, hlm. 8) yaitu:

"Parents positively influence their preschool child's math achievement when they engage in direct (e.g. teaching their children the numbers words and counting and indirect (e.g. integrating numeracy into everyday tasks such as cooking) numeracy practices with their child at home".

Maksudnya adalah orang tua yang positif mempengaruhi prestasi matematika anak prasekolah ketika mereka terlibat langsung (misalnya mengajar menghitung jumlah kata) dan tidak secara langsung (misalnya mengintegrasikan menghitung dalam kehidupan sehari-hari ketika memasak) praktik berhitung dengan anak ketika dirumah.

\section{KESIMPULAN}

Dari hasil temuan dan pengolahan data yang sudah dilakukan, maka peneliti dapat menarik simpulan sebagai berikut:

1. Berdasarkan hasil pengolahan data diketahui bahwa kemampuan membilang Angka 1-10 anak TK Kelompok B Se-Kelurahan Lengkongsari Kota Tasikmalaya berada dalam kriteria berkembang sangat baik. Dengan rata-rata kemampuan membilang angka 110 yaitu sebsar 9,87.

2. Kemampuan menulis anak TK kelompok B Se-Kelurahan Lengkongsari Kota Tasikmalaya dari 45 anak berada dalam kriteria berkembang sangat baik. Dengan rata-rata kemampuan menulis angka 1-10 yaitu sebesar 9,53.

3. Kemampuan penjumlahan yang hasilnya 1-10 anak TTK kelompok B Se-Kelurahan Lengkongsari dari 45 anak terdapat 43 anak yang berada dalam kriteria berkembang sangat baik dan 2 orang berada dalam kriteria berkembang sesuai harapan. Akan tetapi apabila dirata-rata kemampuan penjumlahan anak yaitu sebesar 9,25 dan berada dalam kriteria berkembang sangat baik. 
4. Kemampuan pengurangan yang hasilnya 1-10 anak TK kelompok B Se-Kelurahan Lengkongsari Kota Tasikmalaya dari 45 anak terdapat 41 anak dalam kriteria berkembang sangat baik dan 4 anak berada dalam kriteria berkembang sesuai harapan. Akan tetapi apabila dirata-rata kemampuan pengurangan anak yaitu sebesar 9,08 berada dalam kriteria berkembang sangat baik.

\section{SARAN}

Ada beberapa hal yang peneliti sarankan sebagai berikut: Bagi guru, diharapkan pengenalan tentang simbol + dan - lebih sering dikenalkan. Karena itu dapat menambah pengalaman anak sebelum ke persamaan. Selain itu menggunakan media yang lebih beragam sehingga anak lebih tertarik untuk melakukan kegiatan berhitung permulaan. Peneliti selanjutnya. Peneliti menyadari bahwa dalam penelitian ini masih banyak kekurangan, maka agar penelitian selanjutnya dapat lebih baik kepada peneliti selanjutnya diharapkan: Melakukan penelitian mengenai kemampuan berhitung permulaan pada daerah yang lebih luas lagi, Melakukan penelitian mengenai mengenalkan pengurangan untuk anak usia dini, Melakukan penelitian mengenai cara dan media yang dapat membantu anak memiliki pengetahuan yang benar mengenai penulisan angka.

\section{DAFTAR PUSTAKA}

Amstrong, T. (2003). Sekolah Para Juara: Menerapkan Multiple Intelligences Di Dunia Pendidikan. Bandung: Kaifa

Arikunto, S. (2013). Prosedur Penelitian: Suatu Pendekatan Praktik. Jakarta: PT Rineka Cipta

Aunio, P \& dkk. (2015). The development of early numeracy skills in kindergarten in low-, average- and high- performance
groups:Journal of Early research, 13 (1). hlm 3-16

Beatty, A. (2005). Mathematical and Scientific Development in Early Childhood. Washington: The National Academies Press

Beaty, J.J. (2013). Observasi Perkembangan Anak Usia Dini. Jakarta: Kencana

Cross, C.T, dkk. (2009). Mathematics Learning In Early Childhood:Paths Toward Excellence and Equilty. Washington: The National Press

Departemen Pendidikan Nasional. (2007). Pedoman Pembelajaran Permainan Berhitung Permulaan Di Taman Kanak. Jakarta: Departemen Pendidikan Nasional, Direktorat Jenderal Manajemen Pendidikan Dasar Dan Menengah, Direktorat Pembinaan Taman Kanak-Kanak Dan Sekolah Dasar

Geary, D.C (1994). Children's mathematical development:research and pratctical applications. Washington, DC:American psyhological Association

Lwin, M \& dkk. (2008). How to Multiply Your Child's Intelegence: A practical Guide For Parents of Seven-Year-Old and Below ( Cara Mengembangkan Berbagai Komponen Kecerdasan). Jakarta: PT Indeks

MacDonal, A \& dkk. (2015). Mathematics and Transition To School (international perspectives). Australia: Springer

Maerina, M. (2014). Studi Kemampuan Berhitung Anak TK Kelompok B SeKecamatan Mantrijeron. Yogyakarta: Universitas Negeri Yogyakarta

Martiana, L.D. (2014). Upaya meningkatkan kemampuan berhitung melalui metode bermain dengan media ular tangga pada anak. Jurnal ilmiah PG_PAUD IKIP Veteran Semarang, 2 (2),hlm. 36-47

Morrison, G.S. (2015). Pendidikan Anak Usia Dini Saat Ini. Yogyakarta: Pustaka Pelajar

Reid, K. (2016). Counting on it: early numeracy development and the 
preschool child. Changing minds: Discussion in Neuroscience, Psychology and Education,-,hlml-10.

Soetjiningsih, C.H. (2012). Perkembangan Anak. Jakarta:Prenada

Sugiyono. (2012). Metode Penelitian Pendidikan. Bandung : Alfabeta

Sujiono, Y.N. (2011). Metode Pengembangan Kognitif. Jakarta: Universitas Terbuka

Sujiono, Y.N. (2013). Konsep Dasar Pendidikan Anak Usia Dini. Jakarta: PT Indeks

Susanto, A. (2014). Perkembangan Anak Usia

Dini. Jakarta: Kencana
Suyadi dan Dahlia. (2014). Implementasi dan Inovasi Kurikulum Paud 2013. Bandung:PT Remaja Rosdakarya

Syverson, A. N dan Faith H. Sadler. (2008). Math Is For Everyone: Strategies for Supporting Early Mathematical Competencies in Young Children. Young Exception Children, 11 (3), hlm. $1-16$.

Peraturan Menteri Pendidikan Dan Kebudayaan Nomor 137 tahun 2014 tentang Standar Nasional Pendidikan Anak Usia Dini

Yus, A. (2011). Penilaian Perkembangan Belajar Anak Taman Kanak-Kanak. Jakarta: Kencana 